\title{
Environmental Characteristics and Oxidative Stress of Inhabitants and Patients with Amyotrophic Lateral Sclerosis in a High-incidence Area on the Kii Peninsula, Japan
}

\author{
Tameko Kihira $^{1}$, Kazushi Okamoto ${ }^{2}$, Sohei Yoshida ${ }^{1}$, Tetuya Kondo ${ }^{1}$, Keiko Iwai ${ }^{3}$, \\ Sachiko Wada ${ }^{3}$, Yoshinori Kajimoto ${ }^{4}$, Tomoyoshi Kondo ${ }^{4}$, \\ Yasumasa Kokubo ${ }^{5}$ and Shigeki Kuzuhara ${ }^{5,6}$
}

\begin{abstract}
Objective Although Oshima, in the Kii Peninsula of Japan, is located within a high incidence area of amyotrophic lateral sclerosis (ALS) (Koza/Kozagawa/Kushimoto area, K area), no patients with ALS were detected between 1960 and 1999. However, the incidence recently increased between 2000 and 2009. On Oshima, the source of drinking water was changed from a regional river/wells to the Kozagawa River in the $\mathrm{K}$ area in 1975. We speculate that this change in water source may have played a role in the recent increase in the incidence of ALS. The aim of this study is to find contributing factors that may have triggered the locally high incidence of ALS.

Methods We investigated a possible association between the mineral content of drinking water and serum and oxidative stress markers among patients with ALS in the K area (K-ALS), residents of Oshima and controls.

Results We found that the levels of $\mathrm{Ca}$ and $\mathrm{Zn}$ in the recent drinking water in Oshima are low and that the serum levels of $\mathrm{Ca}$ and $\mathrm{Zn}$ in the Oshima residents and patients with K-ALS were significantly lower, while the oxidative stress markers were significantly higher, than those of the controls. The serum $\mathrm{Zn}$ and urinary $8-\mathrm{OHdG} /$ creatinine levels explained $60 \%$ and $58 \%$ of the variations among the three groups, respectively. The serum $\mathrm{Zn}$ levels were negatively correlated with the serum $\mathrm{Cu}$ levels in the patients with K-ALS, and the serum $\mathrm{Cu}$ levels exhibited a tendency to be positively correlated with the 8-OHdG/creatinine levels in both the patients with K-ALS (r: 0.64) and the residents free from K-ALS (r: 0.32, p<0.01).

Conclusion Taken together, we suggest that the low levels of $\mathrm{Ca}$ and $\mathrm{Zn}$ in the drinking water are possibly associated with an imbalance of metal metabolism in Oshima residents and an increase in oxidative stress markers in patients with K-ALS, although the causative relationship is not clear. This is a cross-sectional study, and a prospective study is needed in the future.
\end{abstract}

Key words: focus area, environment, Kii-ALS, Cu/Zn, 8-OHdG

(Intern Med 52: 1479-1486, 2013)

(DOI: 10.2169/internalmedicine.52.9521)

\footnotetext{
${ }^{1}$ Department of Health Sciences, Kansai University of Health Sciences, Japan, ${ }^{2}$ Department of Public Health, Aichi Prefectural University, Japan, ${ }^{3}$ Faculty of Nursing, Kansai University of Health Sciences, Japan, ${ }^{4}$ Department of Neurology, Wakayama Medical University, Japan, ${ }^{5}$ Department of Neurology, Mie University Graduate School of Medicine, Japan and ${ }^{6}$ Department of Medical Welfare, Suzuka University of Medical Science, Japan

Received for publication December 13, 2012; Accepted for publication February 25, 2013

Correspondence to Dr. Tameko Kihira, tkihira815@kansai.ac.jp
} 


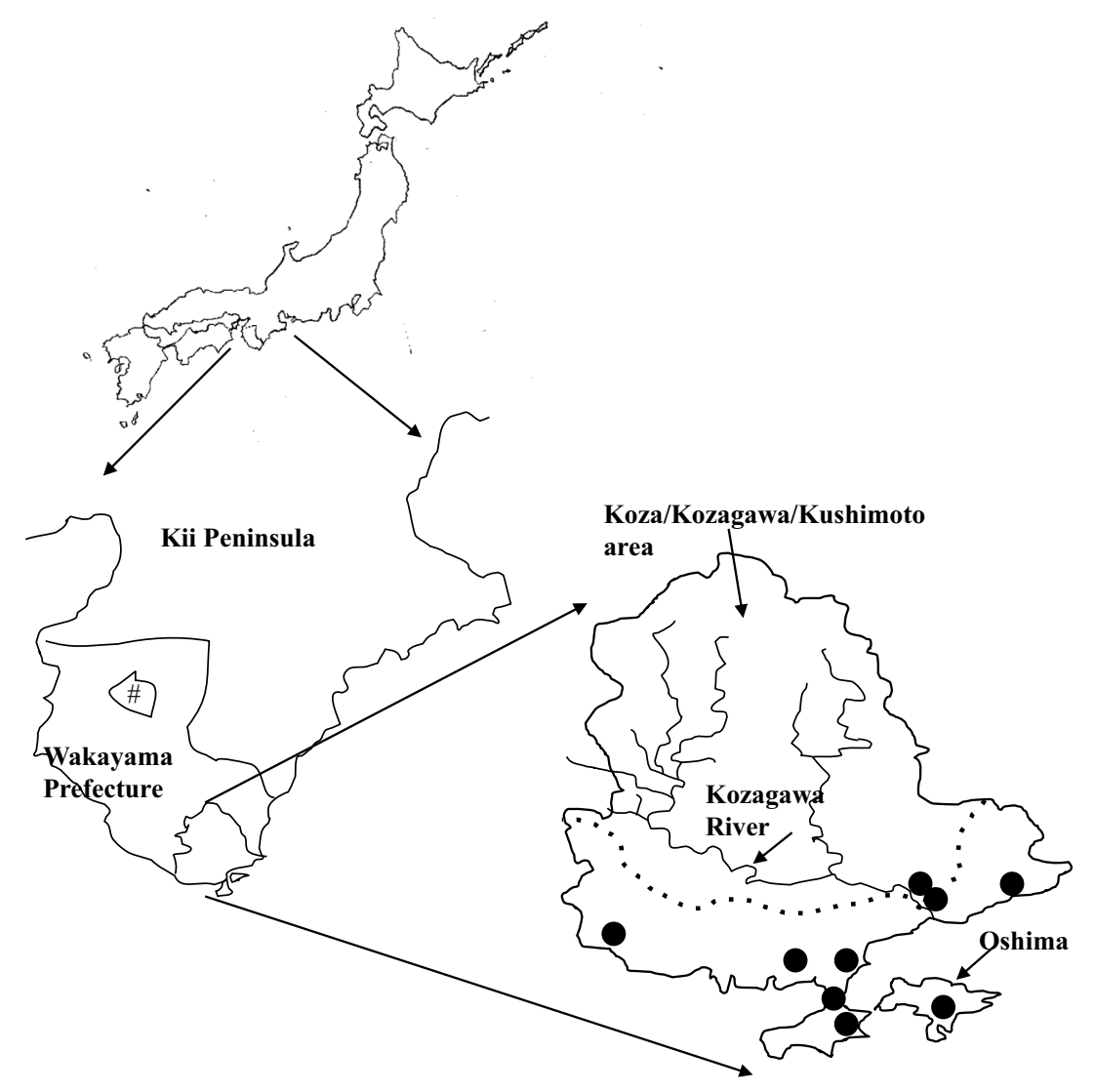

Figure 1. Geography of the Koza/Kozagawa/Kushimoto area and Oshima and the distribution of patients with ALS. The Koza/Kozagawa/Kushimoto (K) area is located in the southern part of the Kii peninsula of Japan. Oshima is included in the $K$ area and is an island opposite to the mainland $K$ area.The control area (\#) is located in the northern part of the Kii peninsula. ALS patients in the $K$ area detected between 2000 and 2009 who participated in the present research are shown.

-: a patient with ALS

\section{Introduction}

Amyotrophic lateral sclerosis (ALS) is a lethal, devastating adult-onset degenerative disease of the upper and lower motor neuron systems of unknown etiology. Many mechanisms have been postulated in the pathogenesis of ALS, including oxidative stress, accumulation of intracellular aggregates, mitochondrial damage, dysfunction in axonal transport, growth factor deficiency, aberrant RNA metabolism, glial cell pathology and Ca-induced excitotoxicity, and it is strongly suggested that interactions between environmental factors and genetic factors are involved in the development of ALS $(1,2)$. The Koza/Kozagawa/Kushimoto $(\mathrm{K})$ area (the southern part of the Kii Peninsula) of Japan exhibited a 10fold higher incidence of ALS compared to other areas of the world in the 1950s and 1960s, as did Guam (3-6). Then, the incidence gradually decreased, and the high incidence focus disappeared in Guam in the 1980s (7). However, the incidence of ALS in the K area recently increased to two- to three-fold higher than that observed in other areas $(8,9)$. On Oshima, a small island opposite the mainland $\mathrm{K}$ area, where the source of drinking water was changed from a regional river, wells and rainfall to the Kozagawa River in the mainland $\mathrm{K}$ area in 1975, we found three patients with ALS after 2000 despite the lack of patients with ALS between 1960 and 1999. The basin area from the Kozagawa River has been reported to be a high-incidence area of ALS in the 1950 s and 1960s $(5,10,11)$. We speculate that the change in water source may consequently have played a role in the appearance of new ALS patients in this area. Aiming to find contributing factors that may have triggered the locally high incidence of ALS, we cross-sectionally investigated a possible association between the drinking water mineral content and the serum mineral levels in residents and patients with ALS in the $\mathrm{K}$ area, with special reference to oxidative stress markers.

\section{Materials and Methods}

\section{Area of investigation}

The Kii Peninsula is located in the central southern part of the Japanese mainland (Fig. 1). Wakayama Prefecture 
Table 1. Levels of Minerals in the Water on Oshima, the Mainland K Area and the Control Areas

\begin{tabular}{lrrr}
\hline Drinking water & Oshima (n: 3) & $\begin{array}{l}\text { The mainland } \\
\text { K area (n: 4) }\end{array}$ & Control (n: 3) \\
\hline $\mathrm{Ca}(\mathrm{mg} / \mathrm{mL})$ & $2.97 \pm 0.06^{*}$ & $4.20 \pm 0.56^{*}$ & $14.97 \pm 5.58$ \\
$\mathrm{Mg}(\mathrm{mg} / \mathrm{mL})$ & $1.10 \pm 0.00$ & $1.53 \pm 0.54$ & $1.90 \pm 0.76$ \\
$\mathrm{Cu}(\mathrm{mg} / \mathrm{mL})$ & $0.013 \pm 0.006$ & $0.025 \pm 0.024$ & $0.023 \pm 0.006$ \\
$\mathrm{Zn}(\mathrm{mg} / \mathrm{mL})$ & $0.009 \pm 0.007$ & $0.013 \pm 0.02$ & $0.012 \pm 0.008$ \\
$\mathrm{Fe}(\mathrm{mg} / \mathrm{mL})$ & $<0.03$ & $<0.03$ & $<0.03$ \\
\hline
\end{tabular}

\begin{tabular}{|c|c|c|c|}
\hline \multicolumn{2}{|c|}{ River water Oshima } & $\begin{array}{l}\text { The mainland } \mathrm{K} \\
\text { area }\end{array}$ & Control \\
\hline $\mathrm{Ca}(\mathrm{mg} / \mathrm{mL})$ & 10.7 & 2.4 & 8.6 \\
\hline $\mathrm{Mg}(\mathrm{mg} / \mathrm{mL})$ & 5.5 & 1.1 & 1.2 \\
\hline $\mathrm{Cu}(\mathrm{mg} / \mathrm{mL})$ & $<0.01$ & $<0.01$ & $<0.01$ \\
\hline $\mathrm{Zn}(\mathrm{mg} / \mathrm{mL})$ & 0.12 & $<0.005$ & $<0.005$ \\
\hline $\mathrm{Fe}(\mathrm{mg} / \mathrm{mL})$ & 0.26 & $<0.03$ & $<0.03$ \\
\hline
\end{tabular}

\begin{tabular}{|c|c|c|c|}
\hline Well water & Oshima & $\begin{array}{l}\text { The mainland } \mathrm{K} \\
\text { area }\end{array}$ & Control \\
\hline $\mathrm{Ca}(\mathrm{mg} / \mathrm{mL})$ & 24.3 & 2.7 & $\overline{14}$ \\
\hline $\mathrm{Mg}(\mathrm{mg} / \mathrm{mL})$ & 5.3 & 2.2 & 2.1 \\
\hline $\mathrm{Cu}(\mathrm{mg} / \mathrm{mL})$ & $<0.01$ & 0.03 & 0.003 \\
\hline $\mathrm{Zn}(\mathrm{mg} / \mathrm{mL})$ & 0.008 & 0.038 & 0.005 \\
\hline $\mathrm{Fe}(\mathrm{mg} / \mathrm{mL})$ & 0.04 & 0.05 & $<0.03$ \\
\hline
\end{tabular}

(population: 1,005,710 in the 2009 census) covers the southwest side of the Kii Peninsula. The Koza/Kozagawa/Kushimoto (K) area (population: 22,633 in the 2009 census, 430.3 $\left.\mathrm{km}^{2}\right)$ is located in the southern part of the Kii peninsula. Oshima (population: 1,217 in the 2009 census, $9.93 \mathrm{~km}^{2}$ ) is an island opposite the mainland $\mathrm{K}$ area and is municipally included in the $\mathrm{K}$ area. The water source of the mainland $\mathrm{K}$ area is the Kozagawa River. On Oshima, the source of drinking water had been regional rivers, wells and rainfall before 1975; however, this was changed to the Kozagawa River after waterworks were installed in 1975. Oshima is a rather isolated, hotel-free and restaurant-free rural area dependent in large part on locally produced food and fishing. There is a local public healthcare and welfare center, a local public hospital, two private hospitals and 19 medical clinics in the $\mathrm{K}$ area.

The control area is a small village, Hanazono, located in the northern part of the Kii Peninsula (Fig. 1). This is a mountainous area where people work in agriculture, forestry and recently tertiary industries. The water source is the local river, and there were no patients with ALS in this area between 1960 and 2009.

\section{Measurement of mineral elements in the water}

In 2009, two-liter water samples from waterworks (drinking water), a regional river and wells from the mainland $\mathrm{K}$ area, Oshima and the control area were collected in polyethylene bottles treated with $10 \%$ hydrochloride to prevent contamination. Drinking water samples were collected at four points in the mainland $\mathrm{K}$ area, three points on Oshima and three points in the control area. The concentrations of $\mathrm{Ca}$, $\mathrm{Mg}, \mathrm{Mn}$ and $\mathrm{Fe}$ were determined using inductively-coupled plasma spectrophotometry (ICP), those of $\mathrm{Al}, \mathrm{Cu}, \mathrm{Zn}, \mathrm{Mo}$, $\mathrm{Se}$ and $\mathrm{Pb}$ were determined using inductively coupled plasma-mass spectrometry (ICP-MS), and that of $\mathrm{Hg}$ was determined using atomic absorption spectrophotometry.

\section{Measurement of elements in the serum and urine of residents and patients with ALS in the $K$ area}

Blood and urine samples were collected from healthy inhabitants over 60 years of age on Oshima and in the control area and patients with probable or definite ALS in the K area (K-ALS). The patients were diagnosed based on the El Escorial criteria for ALS (12) by neurologists in our team at Wakayama Medical University between 2000 and 2009. These participants underwent annual public regional medical examination checkups, including blood chemistry, and participated in this research voluntarily with informed consent. The urine and blood samples were obtained in the morning before breakfast (urine: between 06:30-07:30, blood: 09:0010:30). The serum concentrations of $\mathrm{Ca}$, inorganic phosphorus, intact parathyroid hormone $(\mathrm{PTH}), \mathrm{Zn}, \mathrm{Cu}$ and 8hydroxy-2'-deoxyguanosine (8-OHdG) in the urine samples were determined. The methods used in this analysis were the orthocresolphthalein complexone (OCPC) method for $\mathrm{Ca}$, the molybdic acid ultraviolet absorption method for inorganic phosphorus, electrochemiluminescence (ECLIA) for intact PTH, atomic absorption spectrophotometry for $\mathrm{Zn}$ and $\mathrm{Cu}$ and ELISA for 8-OHdG. The present research was approved by the ethics committee of Wakayama Medical University (No. 289) and the Kansai University of Health Sciences (No. 10-03).

\section{Statistics}

The differences in mean values and ratios were examined using a one-way analysis of variance, the unpaired t-test for continuous variables or the Mann-Whitney test. Two-sided $p$ values of $<0.05$ were considered to be significant. The statistical analyses were conducted using the Statistical Package for the Social Sciences version 14.0 (SPSS Japan, Inc.).

\section{Results}

\section{Measurement of mineral elements in the water}

The mean concentrations of minerals in the drinking water on Oshima are shown in Table 1. The mean Ca level of the drinking water on Oshima was significantly lower than that observed in the control samples. The levels of $\mathrm{Mg}$, $\mathrm{Cu}$ and $\mathrm{Zn}$ in the drinking water on Oshima were also low compared to those observed in the control samples. The concentrations of $\mathrm{Fe}, \mathrm{Al}$ and $\mathrm{Mn}$ in the drinking water were not different between these areas (data not shown). The regional river and well water that was utilized for drinking on Oshima contained higher levels of $\mathrm{Ca}$ and $\mathrm{Mg}$, similar to the control samples, than those observed in the Kozagawa River water and Kozagawa well water. The drinking water in the mainland $\mathrm{K}$ area also contained lower $\mathrm{Ca}$ levels than the control samples. $\mathrm{Hg}, \mathrm{Se}, \mathrm{Pb}$ and $\mathrm{Mo}$ were not detected in any water samples. 
Table 2. Demography and Participants Examined

\begin{tabular}{lccrr}
\hline Area & $\begin{array}{c}\text { Population }>60 \text { y.o. } \\
\text { (Male, Female) \# }\end{array}$ & $\begin{array}{l}\text { Participants } \\
\text { (Male, Female) }\end{array}$ & $\%$ & Mean age (S.D.) \\
\hline Control area & $246(89,157)$ & $51(18,33)$ & 20.7 & $73.0(7.6)$ \\
Oshima & $632(248,384)$ & $146(32,114)$ & 23.1 & $74.5(8.5)$ \\
Patients with ALS in the K area* & $15(8,7)$ & $9(6,3)$ & 60.0 & $65.3(13.8)$ \\
\hline \#: the 2000 census, Japan & & & \\
*: Patients with ALS in the Koza/Kozagawa/Kushimoto (K) area including Oshima between 2000-2009
\end{tabular}
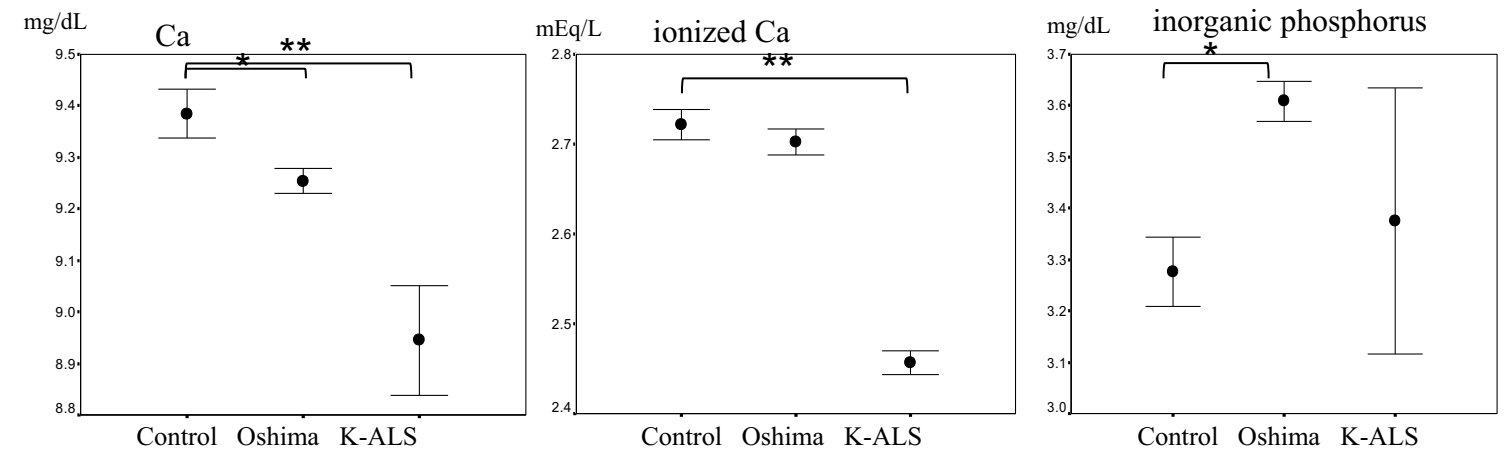

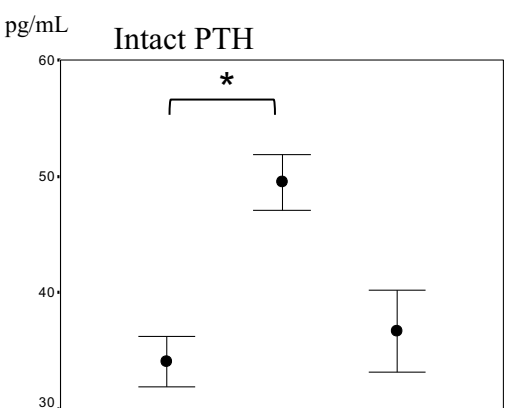

Control Oshima K-ALS

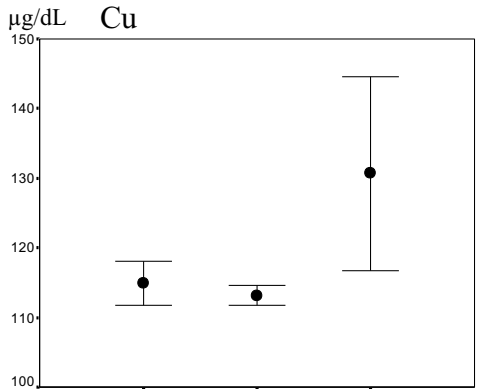

Control Oshima K-ALS

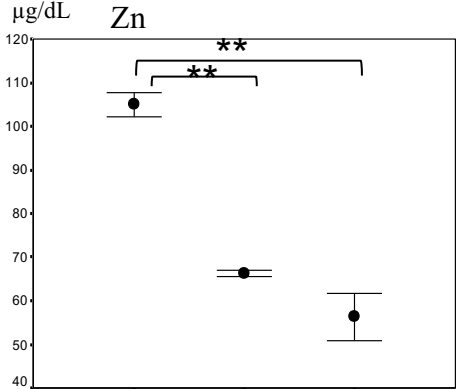

Control Oshima K-ALS

Figure 2. Serum concentrations of $\mathrm{Ca}(\mathrm{mg} / \mathrm{dL})$, ionized $\mathrm{Ca}(\mathrm{mEq} / \mathrm{L})$, inorganic phosphorus $(\mathrm{mg} /$ dL), intact PTH $(\mathrm{pg} / \mathrm{mL}), \mathrm{Cu}(\mu \mathrm{g} / \mathrm{dL})$ and $\mathrm{Zn}(\mu \mathrm{g} / \mathrm{dL})$ in the Oshima residents (O-residents), the ALS patients in the $K$ area (K-ALS) and the controls. The serum Ca concentrations in the Oshima residents $(\mathbf{p}<0.05)$ and the patients with K-ALS $(\mathbf{p}<0.01)$ were lower than those observed in the controls. The mean serum concentrations of inorganic phosphorus and intact PTH in the Oshima residents were higher than those observed in the controls $(p<0.05)$; meanwhile, the levels observed in the patients with ALS exhibited wide variation. The mean serum $\mathrm{Zn}$ concentrations in both the Oshima residents and patients with K-ALS were markedly lower than those observed in the controls ( $\mathbf{p}<0.01$, respectively). The bar indicates the mean \pm S.E.

\section{Measurement of elements in the serum and urine of residents and patients with $\mathrm{K}$-ALS}

Fifty-one residents of the control area, 146 residents on Oshima and nine patients with K-ALS participated in this research (Table 2). Among the patients with K-ALS, the median duration between the onset of the first symptom and the measurement of elements was 36 months (range: 15 to 240 months). The patients with K-ALS exhibited lower $\mathrm{Ca}$ levels $(\mathrm{p}<0.01)$, lower ionized Ca levels $(\mathrm{p}<0.01)$ and lower Zn levels $(p<0.01)$ than the controls. The intact PTH levels of the patients with K-ALS were not different from those of the controls, and the serum levels of inorganic phosphorus and $\mathrm{Cu}$ exhibited wide variation. In the residents of Oshima, the serum levels of $\mathrm{Ca}(\mathrm{p}<0.05)$ and $\mathrm{Zn}(\mathrm{p}<0.01)$ were also lower than those of the controls; however, the levels of inorganic phosphorus $(\mathrm{p}<0.05)$ and intact PTH $(\mathrm{p}<0.05)$ were higher than those of the controls, and the levels of ionized $\mathrm{Ca}$ were not different from those of the controls (Fig. 2). $\mathrm{The} \mathrm{Cu} / \mathrm{Zn}$ ratio, which is reported to be a marker of oxidative stress $(13,14)$, was higher in the patients with K-ALS and the Oshima residents than in the controls $(\mathrm{p}<0.01$, respectively) (Fig. 3). The $8-\mathrm{OHdG}$ level was determined in the patients with K-ALS (all nonsmokers) and non-smoking residents. The mean level of $8-\mathrm{OHdG}$ in the patients with K-ALS was the highest among the three groups $(\mathrm{p}<0.01)$, and that of the Oshima residents was higher than that of the controls $(p<0.05)$. The mean level of $8-\mathrm{OHdG} /$ creatinine (adjusted for creatinine) was the highest in the patients with K-ALS among the three groups (Fig. 3). 


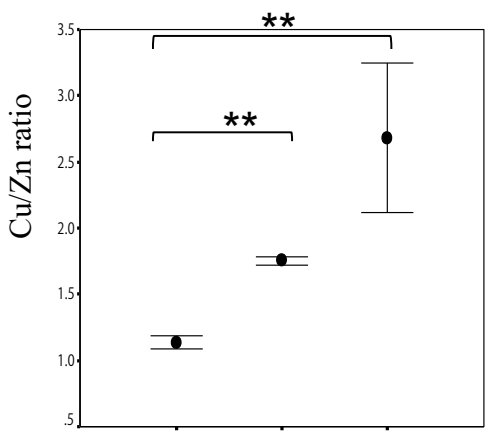

Control O-resident K-ALS
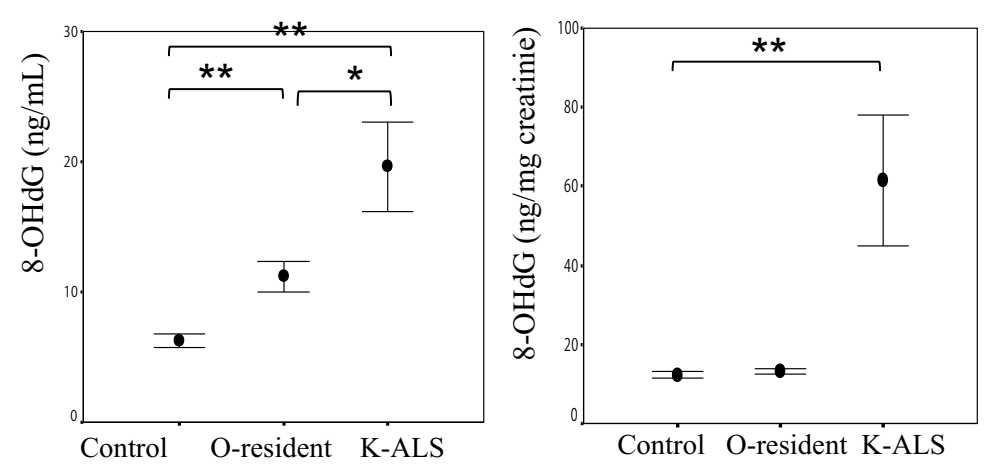

Figure 3. $\mathrm{Cu} / \mathrm{Zn}$ ratios, levels of urinary 8-OHdG $(\mathrm{ng} / \mathrm{mL})$ and levels of 8-OHdG/creatinine in the patients with K-ALS and the Oshima residents (O-resident). The $\mathrm{Cu} / \mathrm{Zn}$ ratios in the patients with K-ALS and the Oshima residents were higher than those observed in the controls $(\mathbf{p}<0.01$, respectively). The mean concentration of 8-OHdG in the non-smoking Oshima residents $(n=55)$ was higher than that observed in the non-smoking controls $(n=35, p<0.05)$. The mean concentrations of 8-OHdG and 8-OHdG/creatinine in the patients with K-ALS (all nonsmokers, $n=6, n g / m L$ ) were the highest among the three groups $(\mathbf{p}<0.01)$. The bar indicates the mean \pm S.E. $*: p<0.05, * *: p<0.01$

The contribution ratios of elements for variance among the patients with K-ALS, the Oshima residents and the controls were analyzed. The serum $\mathrm{Zn}$ levels and urinary 8 $\mathrm{OHdG} /$ creatinine levels exhibited high contribution ratios (0.60, 0.58, respectively) (Table 3 ). The serum $\mathrm{Zn}$ levels were significantly positively correlated with those of serum $\mathrm{Ca}(\mathrm{r}: 0.72)$, inorganic P (r: 0.57) and Fe (r: 0.76) and negatively correlated with those of serum $\mathrm{Cu}(\mathrm{r}:-0.61)$ in the patients with K-ALS. In the residents free from ALS, the serum $\mathrm{Zn}$ levels were positively correlated with the serum levels of $\mathrm{Ca}(\mathrm{r}: 0.24), \mathrm{Fe}$ (r: 0.31) and albumin (r: 0.42), similar to that observed in the patients with K-ALS, and negatively correlated with age (r: -179) and the levels of intact PTH (r: -0.24), inorganic P (r: -0.27) and urinary 8-OHdG (r: -0.25) (Table 4). The 8-OHdG/creatinine levels exhibited a positive correlation with the serum $\mathrm{Cu}$ levels in both the patients with K-ALS (r: 0.64) and the residents free from ALS (r: 0.32, p<0.01) and a negative correlation with the serum intact PTH levels (r: -0.74) in the patients with KALS.

\section{Discussion}

After the water supply was sourced from the Kozagawa River in the mainland K area in 1975, the drinking water on Oshima became markedly low in $\mathrm{Ca}, \mathrm{Mg}, \mathrm{Cu}$ and $\mathrm{Zn}$, similar to that observed in the mainland $\mathrm{K}$ area $(5,10)$. Meanwhile, the water samples from wells and the regional river on Oshima, which had been used on Oshima before 1975, contained high levels of $\mathrm{Ca}$ and $\mathrm{Mg}$.

The residents of Oshima exhibited lower serum $\mathrm{Ca}$ and Zn levels accompanied by higher inorganic phosphorus and intact PTH levels than the controls, while their ionized $\mathrm{Ca}$ levels were maintained at the levels observed in the controls. These results may be explained as a reaction to low intake of $\mathrm{Ca}$ and $\mathrm{Zn}$. The low serum $\mathrm{Ca}$ and high intact PTH levels of the Oshima residents are compatible with our previous findings in residents of the Koza/Kozagawa area (a highincidence area of ALS in which the drinking water contained markedly low levels of $\mathrm{Ca}$ ) who exhibited low serum Ca levels regardless of sufficient intake from food, according to a self-administered food frequency questionnaire survey (15). Epidemiological studies of the relationship between tap water magnesium and calcium concentrations and various diseases have been conducted; however, conflicting results have been reported (16-18). Although prospective studies of metabolic balance, including the mineral levels in drinking water, food and serum, are necessary, the present findings in residents of Oshima may be partly explained by the recent change in drinking water source.

The patients with ALS in the $\mathrm{K}$ area exhibited severely low serum ionized $\mathrm{Ca}$ as well as serum total $\mathrm{Ca}$ and $\mathrm{Zn} \mathrm{lev-}$ els without significant elevation of the intact PTH levels, which is significantly different from that observed in the Oshima residents. The low levels of intact PTH observed in the patients with K-ALS may be due to exhaustion of the parathyroid gland due to a possible longstanding $\mathrm{Ca}$ imbalance, wide fluctuation of the serum element levels or an unknown indigenous vulnerability in mineral metabolism, although the mechanisms were not clear.

The levels of $\mathrm{Zn}$ and 8-OHdG/creatinine explained $60 \%$ and $58 \%$ of the variance observed among the patients with K-ALS, the Oshima residents and the controls. Urinary 8OHdG, an oxidized nucleoside of DNA, is excreted in the urine upon DNA repair and is regarded to be not only a biomarker of generalized cellular oxidative stress, but also a risk factor for cancer, atherosclerosis and diabetes (19). The levels of $8-\mathrm{OHdG} /$ creatinine in morning spot urine are reported to correlate with the $8-\mathrm{OHdG}$ levels in 24-hour pool urine (20). We herein reported for the first time that the morning spot urinary $8-\mathrm{OHdG}$ and $8-\mathrm{OHdG}$ /creatinine levels were significantly higher in the patients with ALS in the K 
Table 3. Contribution Ratios of Each Element for Variance among the Patients with K-ALS, the Oshima Residents (O-resident) and the Controls

\begin{tabular}{|c|c|c|c|c|c|}
\hline & Group & Mean & S.D. & $\mathrm{p}$ & $\begin{array}{c}\text { Contribution } \\
\text { ratio }\end{array}$ \\
\hline \multirow[t]{3}{*}{$\mathrm{Ca}(\mathrm{mg} / \mathrm{dL})$} & Control & 9.38 & 0.34 & $<0.01$ & 0.05 \\
\hline & O-resident & 9.25 & 0.35 & & \\
\hline & K-ALS & 8.94 & 0.32 & & \\
\hline \multirow[t]{3}{*}{ ionized $\mathrm{Ca}(\mathrm{mEq} / \mathrm{L})$} & Control & 2.72 & 0.12 & $<0.01$ & 0.19 \\
\hline & O-resident & 2.7 & 0.12 & & \\
\hline & K-ALS & 2.46 & 0.03 & & \\
\hline \multirow{3}{*}{$\begin{array}{l}\text { inorganic phosphorus } \\
(\mathrm{mg} / \mathrm{dL})\end{array}$} & Control & 3.28 & 0.48 & $<0.01$ & 0.08 \\
\hline & O-resident & 3.61 & 0.47 & & \\
\hline & K-ALS & 3.38 & 0.73 & & \\
\hline \multirow[t]{3}{*}{ intact PTH (pg/mL) } & Control & 34.08 & 15.42 & $<0.01$ & 0.16 \\
\hline & O-resident & 49.48 & 19.13 & & \\
\hline & K-ALS & 36.71 & 9.32 & & \\
\hline \multirow[t]{3}{*}{$\mathrm{Cu}(\mathrm{mg} / \mathrm{dL})$} & Control & 114.88 & 22.64 & 0.07 & 0.02 \\
\hline & O-resident & 113.16 & 21.6 & & \\
\hline & K-ALS & 130.67 & 41.79 & & \\
\hline \multirow[t]{3}{*}{$\mathrm{Zn}(\mathrm{mg} / \mathrm{dL})$} & Control & 105.02 & 19.92 & $<0.01$ & 0.60 \\
\hline & O-resident & 66.23 & 10 & & \\
\hline & K-ALS & 56.33 & 16.12 & & \\
\hline \multirow[t]{3}{*}{$\mathrm{Cu} / \mathrm{Zn}$} & Control & 1.14 & 0.34 & $<0.01$ & 0.23 \\
\hline & O-resident & 1.74 & 0.47 & & \\
\hline & K-ALS & 2.68 & 1.7 & & \\
\hline 8-OHdG (ng/mL) & Control & 6.24 & 3.03 & $<0.01$ & 0.19 \\
\hline \multirow[t]{2}{*}{ (without smoking habit) } & O-resident & 11.19 & 8.6 & & \\
\hline & K-ALS & 19.62 & 8.4 & & \\
\hline 8-OHDdG (ng/mg creatinine) & Control & 12.32 & 4.48 & $<0.01$ & 0.58 \\
\hline \multirow[t]{2}{*}{ (without smoking habit) } & O-resident & 13.1 & 4.4 & & \\
\hline & K-ALS & 61.53 & 40.26 & & \\
\hline \multirow[t]{3}{*}{$\mathrm{Fe}(\mathrm{mg} / \mathrm{dL})$} & Control & 104 & 41.43 & $<0.01$ & 0.06 \\
\hline & O-resident & 84.84 & 29 & & \\
\hline & K-ALS & 57.67 & 44.93 & & \\
\hline \multirow[t]{3}{*}{ Albumin (mg/dL) } & Control & 4.25 & 0.27 & $<0.01$ & 0.10 \\
\hline & O-resident & 4.19 & 0.26 & & \\
\hline & K-ALS & 3.71 & 0.58 & & \\
\hline
\end{tabular}

Table 4. Correlation Coefficients between Elements among the Patients with K-ALS and Residents Free from ALS

\begin{tabular}{|c|c|c|c|c|}
\hline & \multicolumn{2}{|c|}{ serum $\mathrm{Zn}$} & \multicolumn{2}{|c|}{ 8-OHdG/creatinine } \\
\hline & K-ALS & Residents & K-ALS & Residents \\
\hline & $\mathrm{r}$ & $\mathrm{r}$ & $\mathrm{r}$ & $\mathrm{r}$ \\
\hline serum $\mathrm{Ca}$ & $0.72 *$ & $0.24 * *$ & -0.46 & -0.15 \\
\hline serum ionized $\mathrm{Ca}$ & 0.58 & 0.14 & -0.21 & -0.14 \\
\hline serum $\mathrm{Zn}$ & & & -0.51 & -0.13 \\
\hline serum $\mathrm{Cu}$ & $-0.61 \#$ & -0.04 & 0.64 & $0.32 * *$ \\
\hline intact PTH & 0.57 & $-0.24 *$ & $-0.74 \#$ & 0.11 \\
\hline inorganic $\mathrm{P}$ & $0.67 \#$ & $-0.27 * *$ & -0.28 & 0.14 \\
\hline $\mathrm{Fe}$ & $0.76 \#$ & $0.31 * *$ & -0.42 & 0.04 \\
\hline albumin & 0.48 & $0.42 * *$ & -0.66 & -0.02 \\
\hline age & 0.42 & $-0.179 *$ & 0.029 & 0.095 \\
\hline clinical duration & -0.002 & & -0.103 & \\
\hline urinary $8-\mathrm{OHdG}$ & -0.11 & $-0.25 *$ & -0.32 & $0.54 * *$ \\
\hline 8-OHdG/creatinine & -0.51 & -0.1 & & \\
\hline
\end{tabular}

area than in the controls. Increases in the levels of urinary 8-OHdG have been reported in patients with ALS/PDC (parkinsonism-dementia complex) in Hohara, another highincidence area of ALS/PDC in the Kii peninsula (21), patients with spinal and bulbar muscular atrophy (22) and patients with Parkinson's disease (23). In the future, it is necessary to study whether increases in the levels of $8-\mathrm{OHdG}$ and $8-\mathrm{OHdG} /$ creatinine are specific to ALS patients in this area.

The $\mathrm{Cu} / \mathrm{Zn}$ ratio is also regarded to be an oxidative stress marker $(13,14)$, and competition between $\mathrm{Zn}$ and $\mathrm{Cu}$ for absorption sites in the gut and an antagonistic correlation between $\mathrm{Zn}$ and $\mathrm{Cu}$ have been previously observed in healthy subjects and patients with various diseases $(24,25)$. Zn deficiency has been reported to affect DNA damage and DNA repair (26), decrease the antioxidant defense system and increase oxidative stress in the erythrocytes of rats (27). Marginal Zn deficiency impairs Ca utilization in rats (28), and coupled $\mathrm{Ca}$ and $\mathrm{Zn}$ dyshomeostasis increases oxidative stress in rat cardiac myocytes (29). Significant increases in the $\mathrm{Cu}$ ion levels have been found in the spinal cord in a mouse model of ALS. In addition, $\mathrm{Cu}$-chelating drugs extended the lifespan of mice, while $\mathrm{Cu}$ nanoparticles easily enter the brain and exert heavy metal-induced neurotoxicity in experimental animals $(30,31)$. Interactions among $\mathrm{Ca}$, $\mathrm{Zn}, \mathrm{Cu}$ and other trace metals are important for mineral homeostasis (32), and imbalances among trace metals are toxic, leading to neuronal apoptosis (33).

In the present study, low serum $\mathrm{Zn}$ and $\mathrm{Ca}$ levels, high $\mathrm{Cu} / \mathrm{Zn}$ ratios and high urinary $8-\mathrm{OHdG}$ levels were commonly found in the patients with ALS in the $\mathrm{K}$ area and the Oshima residents. The serum $\mathrm{Zn}$ levels were negatively correlated with the serum $\mathrm{Cu}$ levels in the patients with ALS, 
while the serum $\mathrm{Cu}$ levels exhibited a tendency towards a positive correlation with the urinary $8-\mathrm{OHdG} / \mathrm{creatinine}$ levels in both the patients with ALS and the residents free from ALS. Taken together, the relative $\mathrm{Cu}$ excess compared to the Zn levels may be associated with a risk of increasing oxidative stress in the patients with K-ALS and also possibly in the Oshima residents $(13,14)$, although the mechanism is unclear. It has been suggested that severely low levels of $\mathrm{Ca}$ and $\mathrm{Zn}$ in the river and drinking water are an environmental characteristic of this area that may have some sort of association with the lower levels of serum $\mathrm{Ca}$ and $\mathrm{Zn}$ and the higher oxidative stress markers observed in the residents and patients with ALS in the $\mathrm{K}$ area compared to that observed in the controls, although the causal relationship is unclear. Whether these environmental characteristics play a role in susceptible subjects with possible genetic vulnerabilities to ALS in this area (34-36) should be investigated in future prospective studies.

The authors state that they have no Conflict of Interest (COI).

\section{Acknowledgement}

The authors especially thank Prof. Yoshiro Yase of Kansai University of Health Sciences, Prof. Fumio Yoshimasu of Kansai University of Health Sciences and Prof. Ralph M. Garruto of the State University of New York at Binghamton for their helpful advice and encouragement. The authors also thank Prof. Mikio Arita and Prof. Miyoko Utsumi of Wakayama Medical University for their helpful cooperation.

This work was supported by Grants-in-Aid from the Research Committee of Muro Disease (Chairman: Dr. Yasumasa Kokubo), the Ministry of Health, Labour and Welfare of Japan and a Grant-in-Aid for Scientific Research of Japan (No. 22590967 and No. 16590511).

\section{References}

1. Rothstein JD. Current hypotheses for the underlying biology of amyotrophic lateral sclerosis. Ann Neurol 65 Suppl 1: S3-S9, 2009.

2. Lynch D, Wanglund C, Spathis R, et al. The contribution of mitochondrial dysfunction to a gene-environment model of Guamanian ALS and PD. Mitochondrion 8: 109-116, 2008.

3. Kimura K. Studies of amyotrophic lateral sclerosis in the Kozagawa district in the Kii Peninsula. Jpn. Wakayama Med J 9: 177192, 1965.

4. Yase Y, Matsumoto N, Azuma K, Nakai Y. Amyotrophic Lateral Sclerosis. Association with schizophrenic syndromes and showing Alzheimer's tangles. Arch Neurol 27: 118-128, 1972.

5. Yase Y. The pathogenesis of amyotrophic lateral sclerosis. Lancet 2: 292-296, 1972.

6. Kurland LT, Mulder DW. Epidemiologic investigations of amyotrophic lateral sclerosis. 1. Preliminary report on geographic distribution, with special reference to the Mariana Islands, including clinical an pathological observations. Neurology 4: 355-378, 438-448, 1954.

7. Garruto RM, Yanagihara R, Gajdusek DC. Disappearance of high incidence amyotrophic lateral sclerosis and parkinsonism-dementia on Guam. Neurology 35: 193-198, 1985.

8. Kihira T, Yoshida S, Hironishi M, Miwa H, Okamoto K, Kondo T. Changes in the incidence of amyotrophic lateral sclerosis in
Wakayama, Japan. Amyotrophic Lateral Scler Other Motor Neuron Disord 6: 155-163, 2005.

9. Kihira T, Yoshida S, Kondo T, et al. An increase in ALS incidence on the Kii Peninsula, 1960-2009: A possible link to change in drinking water source. Amyotrophic Lateral Scler 13: 347-350, 2012.

10. Garruto RM, Yanagihara R, Gajdusek DC, Arion DM. Concentrations of heavy metals and essential minerals in garden soil and drinking water in the Western Pacific. In: AMYOTROPHIC LATERAL SCLEROSIS IN ASIA AND OSEANIA. Chen KM, Yase Y, Eds. NATIONAL TAIWAN UNIVERSITY, SHYAN-FU CHOU, 1984: 265-330.

11. Iwami O, Moon CS, Watanabe T, Ikeda M. Association of metal concentrations in drinking water with the incidence of motor neuron disease in a focus on the Kii Peninsula of Japan. Bull Environ Contam Toxicol 52: 109-116, 1994.

12. World Federation of Neurology Subcommittee on Motor Neuron Disease. El Escorial World Federation of Neurology criteria for the diagnosis of amyotrophic lateral sclerosis. J Neurol Sci $\mathbf{1 2 4}$ (suppl): 98-107, 1994.

13. Mezzetti A, Pierdomenico SD, Costantini F, et al. Copper/zinc ratio and systemic oxidant load: effect of aging and aging-related degenerative diseases. Free Radic Biol Med 25: 676-681, 1998.

14. Guo $\mathrm{CH}$, Chen PC, Yeh MS, Hsiung DY, Wang CL. Cu/Zn ratios are associated with nutritional status, oxidative stress, inflammation, and immune abnormalities in patients on peritoneal dialysis. Clin Biochem 44: 275-280, 2011.

15. Kihira $T$, Okamoto $K$, Yoshida $S$, Kondo $T$, Nagai M. Metal analysis of inhabitants in a high-incidence area of amyotrophic lateral sclerosis and patients with the disease in Kii Peninsula, Japan. NEUROLOGICAL MEDICINE 73: 507-512, 2010.

16. Yang CY. Calcium and magnesium in drinking water and risk of death from cerebrovascular disease. Stroke 29: 411-414, 1998.

17. Rosenlund M, Berglind N, Hallqvist J, Bellander T, Bluhm G. Daily intake of magnesium and calcium from drinking water in relation to myocardial infarction. Epidemiology 16: 570-576, 2005.

18. Kohri K, Ishikawa Y, Iguchi M, Kurita T, Okada Y, Yoshida O. Relationship between the incidence infection stones and the magnesium-calcium ratio of tap water. Urol Res 21: 269-272, 1993.

19. Wu LL, Chiou CC, Chang PY, et al. Urinary 8-OHdG: a marker of oxidative stress to DNA and a risk factor for cancer, atherosclerosis and diabetics. Clin Chim Acta 339: 1-9, 2004.

20. Miwa M, Matsmura H, Akimoto $\mathrm{Y}$, et al. Quantitative determination of urinary 8-hydroxy-2'-deoxyguanosine level in health Japanese. Biofactors 22: 249-253, 2004.

21. Morimoto S, Kuzuhara S, Kokubo Y. Increased oxidative stress in patients with amyotrophic lateral sclerosis/Parkinsonism-dementia complex in the Kii peninsula, Japan. Mov Disord 24: 123-126, 2009.

22. Mano T, Katsuno M, Banno H, et al. Cross-sectional and longitudinal analysis of an oxidative stress biomarker for spinal and muscular atrophy. Muscle Nerve 46: 692-697, 2012.

23. Sato S, Mzuno Y, Hattori N. Urinary 8-hydroxydeoxyguanosine levels as a biomarker for progression of Parkinson disease. Neurology 64: 1081-1083, 2005.

24. Elinder CG, Piscator M. Zinc. In: Handbook on the Toxicology of Metals. Friberg L, et al, Eds. Elsevier/North Holland Biomedical Press, 1979: 675-685.

25. Minato A, Ogiso T. Studies on metalloprotein. IX. The effects of excessive dietary zinc on serum copper and oxidase activity of ceruloplasmin. YAKUGAKU ZASSHI 86: 521-524, 1966.

26. Song Y, Leonard SW, Traber MG, Ho E. Zinc deficiency affects DNA damage, oxidative stress, antioxidant defenses, and DNA repair in rats. J Nutr 139: 1626-1631, 2009.

27. Taysi S, Cikman O, Kaya A, et al. Increased oxidant stress and decreased antioxidant status in erythrocytes of rats fed with zinc- 
deficient diet. Biol Trace Elem Res 123: 161-167, 2008.

28. Nielsen FH. Marginal zinc deficiency increases magnesium retention and impairs calcium utilization in rats. Biol Trace Elem Res 128: 220-231, 2009.

29. Kamalov G, Deshmukh PA, Baburyan NY, et al. Coupled calcium and zinc dyshomeostasis and oxidative stress in cardiac myocytes and mitochondria of rats with chronic aldosterosnism. J Cardiovasc Pharmacol 53: 414-423, 2009.

30. Tokuda $\mathrm{E}$, Ono $\mathrm{S}$, Ishige $\mathrm{K}$, et al. Ammonium tetrathiomolybdate delays onset, prolongs survival, and slows progression of disease in a mouse model for amyotrophic lateral sclerosis. Exp Neurol 213: 122-128, 2008.

31. Sharma HS, Sharma A. Neurotoxicity of engineered nanoparticles from metals. CNS Neurol Disord Drug Targets 1: 65-80, 2012.

32. Weisstaub A, de Ferrer PR, Zeni S, de Portela ML. Influence of low dietary calcium during pregnancy and lactation on zinc levels in maternal blood and bone in rats. $\mathrm{J}$ Trace Elem Med Biol 17: 27-32, 2003.

33. Levenson CW. Trace metal regulation of neuronal apoptosis: from genes to behavior. Physiol Behav 86: 399-406, 2005.

34. Hara K, Kokubo Y, Ishiura $H$, et al. TRPM7 is not associated with amyotrophic lateral sclerosis-parkinsonism dementia complex in the Kii peninsula of Japan. Am J Med Genet B Neuropsychiatr Genet 153B: 310-313, 2010.

35. Ishiura $\mathrm{H}$, Takahashi $\mathrm{Y}$, Mitsui J, et al. C90RF72 repeat expansion in amyotrophic lateral sclerosis in the Kii peninsula. Arch Neurol 4: 1-5, 2012.

36. Naruse H, Takahashi Y, Kihira T, et al. Mutational analysis of familial and sporadic amyotrophic lateral sclerosis with OPTN mutations in Japanese population. Amyotroph Lateral Scler 13: 562566, 2012.

(C) 2013 The Japanese Society of Internal Medicine http://www.naika.or.jp/imonline/index.html 